\title{
PALB2 wt Allele
}

National Cancer Institute

\section{Source}

National Cancer Institute. PALB2 wt Allele. NCI Thesaurus. Code C84946.

Human PALB2 wt allele is located in the vicinity of $16 \mathrm{p} 12.1$ and is approximately $38 \mathrm{~kb}$ in length. This allele, which encodes partner and localizer of BRCA2 protein, may play roles in the repair of damaged DNA and DNA damage-induced checkpoints. Mutations in this gene are associated with about 3\% of pancreatic carcinomas. 